\title{
Studi Respon Siswa SMP Terhadap Levels Of Inquiry Model Pada Pembelajaran IPA
}

\author{
Novia $^{1}$, Riandi $^{2}$, Noor Novianawati ${ }^{3}$ \\ ${ }^{1}$ Program Studi Pendidikan Guru Sekolah Dasar, Universitas Tadulako, Indonesia \\ ${ }^{2}$ Sekolah Pascasarjana, Universitas Pendidikan Indonesia, Indonesia \\ ${ }^{3}$ Program Studi Pendidikan IPA, Universitas Muhammadiyah Cirebon, Indonesia \\ novia@untad.ac.id
}

\begin{abstract}
Abstrak
Penelitian ini bertujuan untuk mendeskripsikan respon siswa terhadap pembelajaran levels of inquiry model pada pembelajaran IPA secara keseluruhan dan berdasarkan setiap aspeknya. Terdapat sembilan aspek yang terkait dengan respon siswa pada terhadap Levels of Inquiry Model. Selain itu, penelitian ini bertujuan untuk memperoleh gambaran informasi mengenai subjek penelitian. Respon siswa diukur mengunakan Skala Guttman dengan jumlah pertanyaan sebanyak 9 soal. Selain menggunakan kuesioner, penelitian ini juga menggunakan instrumen wawancara terstruktur. Metode penelitian yang dipilih dalam penelitian ini adalah metode deskriptif kuantitatif. Populasi dalam peneitian ini adalah seluruh siswa SMP kelas VII tahun ajaran 2014/2015 di SMP Laboratorium Percontohan UPI Bandung. Sampel dari penelitian ini adalah salah satu kelas VII yaitu kelas VII C. Metode pengambilan sampel yang digunakan dalam penelitian ini adalah purposive sampling. Hasil penelitian menunjukkan bahwa secara kuantitatif dapat dikatakan bahwa hampir semua siswa $(86,7 \%)$ menyukai pembelajaran yang dilakukan dengan model levels of inquiry dengan berbagai alasan, seperti dapat lebih aktif belajar, menyenangkan, lebih memahami materi yang disajikan, menemukan konsep sendiri dan menjadi lebih bersemangat. Hal ini menunjukkan bahwa siswa siap belajar karena telah biasa melakukan pembelajaran levels of inquiry dan memiliki motivasi yang tinggi untuk melaksanakan pembelajarannya.
\end{abstract}

Kata Kunci : Respon Siswa, Levels of Inquiry, IPA

\begin{abstract}
This study aims to determine the response of students to the learning levels of inquiry model in science learning as a whole and based on every aspect. There are nine aspects related to the student's response to the Levels of Inquiry Model. In addition, this study aims to obtain an overview of information on the subject of research. Student responses were measured using Guttman Scale with a total of 9 questions. In addition to using questionnaires, this study also uses structured interview instruments. The research method chosen in this research is quantitative descriptive method. The population in this study is all students of SMP class VII academic year 2014/2015 at SMP Laboratory UPI Bandung. The sample of this research is one of class VII that is class VII C. Sampling method used in this research is purposive sampling. The results of research indicate that quantitatively it can be said that almost all students (86.7\%) prefer learning by model levels of inquiry with various reasons, such as being more active learning, fun, better understanding of the material presented, finding their own concepts and becoming more excited. This indicates that students are ready to learn because they have been accustomed to learning level of inquiry and have high motivation to carry out their learning.
\end{abstract}

Keywords: Student Response, Levels of Inquiry, IPA

\section{PENDAHULUAN}

Pembelajaran Ilmu Pengetahuan Alam

(IPA) bertujuan untuk mempersiapkan siswa agar mempunyai pemahaman tentang sains melalui pengembangan keterampilan berpikir, sikap dan keterampilan dalam upaya memahami dirinya supaya bisa mengelola lingkungan dan mengatasi masalah yang 
berhubungan dengan IPA dan lingkungannya. IPA menduduki salah satu posisi yang paling penting untuk siswa dalam menghadapi kehidupan masa mendatang (Rustaman, 2007). Dalam jangka panjang, tujuan pembelajaran IPA adalah memberikan kemampuan berpikir kritis, logis, sistematis dan bersikap kreatif, tekun, disiplin, percaya diri, memiliki keterampilan kerja, keterampilan komunikasi dan keterampilan sosial lainnya yang menjadi kemampuan dasar bekerja ilmiah untuk menghadapi tantangan yang semakin kompetititf (Rustaman, 2007).

Kemampuan dasar bekerja ilmiah merupakan perluasan dari metode ilmiah yang diartikan sebagai scientific inquiry. Inkuiri telah dianggap sebagai strategi penting dan efisien untuk memajukan pembelajaran IPA (Novia, 2018). Inkuiri memfasilitasi siswa belajar, bekerja dan mengajukan pertanyaan dengan lebih baik dari pada pendekatan laboratorium tradisional (Hofstein,Navon, Kipnis \& Mamlok-Naaman, 2005). Inkuiri yang seharusnya mendorong penalaran ilmiah siswa sebagai salah satu tujuan utama dari pendidikan sains tidak terpenuhi. (American Association for the Advancement of Science,1993, National Research Council (NRC), 1996 ).

Inkuiri memberikan kepada siswa pengalaman-pengalaman belajar kreatif dannyata. Siswa diharapkan mengambil inisiatif, mereka dilatih bagaimana memecahkan masalah, membuat keputusan, dan memperoleh keterampilan. Inkuiri memungkinkan siswa dalam berbagai tahap perkembangannya bekerja dengan masalahmasalah yang sama dan bahkan mereka bekerja sama mencari solusi terhadap masalahmasalah yang telah mereka temukan. Mengingat pentingnya hasil dari inquiry, maka sudah seyogyanya pembelajaran IPA di sekolah dikelola sedemikian rupa sehingga mampu memfasilitasi peserta didik untuk mengembangkan higher order thinking menggunakan inquiry pada konsep yang dipelajarinya (Novia, 2017)

Berdasarkan hasil pengamatan langsung di salah satu SMP di Kota Bandung, yang dilakukan dengan salah satu guru IPA menyatakan bahwa pembelajaran di kelas belum berbasis inkuiri secara menyeluruh karena masih jarang dilakukan eksperimen. Sehingga tidak menuntut siswa untuk berpikir tingkat tinggi dan cenderung hanya menghafalkan rumus-rumus. Sesekali dilakukan inkuiri dalam pembelajaran namun tidak melibatkan siswa secara penuh dalam penyelidikan ilmiah dan merencanakan suatu percobaan. Padahal penyelidikan ilmiah dan konten pengetahuan saling berhubungan untuk mendasari pengembangan berpikir ilmiah.

Alternatif solusi yang dipandang dapat mengatasi masalah tersebut adalah dengan menerapkan model inkuiri. Sudah banyak guru yang menerapkan berbagai jenis pendekatan inkuiri seperti discovery learning, guided inquiry, ataupun free inquiry di dalam 
pembelajaran IPA. Akan tetapi fakta menunjukkan bahwa guru tersebut sekedar menerapkannya tanpa disertai adanya pemahaman yang komprehensif dalam menggunakannya (Wenning, 2010, hal 11). Akibatnya banyak pendekatan inkuiri di sekolah yang diterapkan secara terputus-putus (disconnected process), prosesnya tidak sistematis (random inquiry processes) dan seringkali gagal melatihkan intellectual processes skills yang berguna untuk mengembangkan pemahaman siswa (Wenning 2011, hal 10; 2011, hal 17).

Levels of inquiry models merupakan unipolar rangkaian inkuiri yang terdiri dari enam tingkatan diawali dengan tingkat dasar hingga tingkat paling tinggi (Novia, 2015). Tingkatan tersebut adalah discovery learning, interactive demonstrative, inquiry lesson,inquiry lab, real-world application dan hypothetical inquiry. (Wenning 2010). Keenam tingkatan tersebut diurutkan berdasarkan kemampuan intelektual siswa dan pihak pengontrol. Semakin tinggi tingkat inkuiri semakin tinggi pula kemampuan intelektualnya. Wenning (2005) menjelaskan bahwa inkuiri yang dilakukan secara sistematis berdampak pada proses transfer pengetahuan yang berjalan dengan lebih efektif.

Berdasarkan penelitian yang telah dilakukan oleh Suprihatin (2014) penerapan model pembelajaran inkuiri terbimbing pada konsep pencemaran lingkungan dalam melatih keterampilan menyelesaikan masalah menunjukkan bahwa hasil belajar siswa dalam pembelajaran pada konsep pencemaran lingkungan, keterampilan menylesaikan masalah, psikomotor siswa, keterampilan sosial siswa, pengelolaan pembelajaran keterampilan berkomunikasi siswa adanya peningkatan, dan siswa memberikan respon positif terhadap pelaksanaan pembelajaran dengan model pembelajaran inkuiri terbimbing yang diketahui dari banyaknya siswa yang menjawab "Senang". Selanjutnya penelitian yang dilakukan oleh Mustikaweni, dkk (2015) tentang Pengaruh Respon Siswa Terhadap Model Pembelajaran Inkuiri Terbimbing Dalam Menghadapi Masyarakat Ekonomi Asia menunjukkan bahwa respon siswa selama kegiatan pembelajaransetelah diterapkan model pembelajaran inkuiri terbimbing pada materi perpindahan kalor sangat positif dan diterima baik oleh siswa.

Beberapa penelitian sebelumnya telah melakukan penelitian mengenai respon siswa mengenai inquiry tapi bukan mengenai Levels of inquiry pada pembelajaran IPA terpadu. Berdasarkan latar belakang yang telah diungkapkan di atas, maka peneliti tertarik untuk mengetahui respon siswa terhadap levels of inquiry model pada pembelajaran IPA. Penelitian ini merupakan penelitian deskriptif kuantitatif yang menggambarkan semua kegiatan, kondisi, kejadian, aspek komponen sebagaimana adanya dan gambarannya menggunakan ukuran atau frekuensi. 


\section{METODE PENELITIAN}

Metode penelitian yang dipilih dalam penelitian ini adalah metode penelitian deskriptif kuantitatatif. Satu-satunya unsur manipulasi atau pengambilan data yang diberikan hanyalah penelitian itu sendiri, yang dilakukan melalui observasi, wawancara, pengedaran angket atau studi dokumentasi. (Sukmadinata, 2012:73).

\section{Jenis Penelitian}

Penelitian ini menggunakan pendekatan kuantitatif. Penelitian ini tidak mengadakan manipulasi atau pengubahan pada variabelvariabel bebas tetapi menggambarkan suatu kondisi apa adanya. Desain penelitian yang digunakan adalah One Group Pretes-Posttest Design. Dalam desain ini tidak terdapat kelompok pembanding atau kontrol (Creswell, 1994, hlm 130).

\section{Waktu dan Tempat Penelitian}

Penelitian ini dilakukan pada bulan April tahun 2015 di Sekolah Percontohan Laboratorium (Labschool) UPI, Bandung. Metode pengambilan sampel yang digunakan dalam penelitian ini adalah nonrandom sampling yaitu pengambilan sampel yang tidak memberikan peluang yang sama bagi setiap anggota populasi untuk dipilih menjadi anggota sampel (Best, 2006).

Adapun teknik sampling yang digunakan ialah purposive sampling yaitu pengambilan anggota sampel dari populasi yang dilakukan dengan pertimbangan tertentu. Beberapa pertimbangan yang dijadikan alasan pemilihan sampel adalah rekomendasi dari guru di lokasi penelitian yang mengetahui kondisi siswa yang mengnjurkan kelas yang lebih mudah dikondisikan dan siswanya lebih aktif dalam pembelajaran.

\section{Subjek Penelitian}

Subjek penelitian dipilih berdasarkan pertimbangan guru yang direkomendasikan kepada peneliti. Siswa dari 10 kelas yang menjadi populasi dilihat tingkat kecerdasannya berdasarkan nilai hasil belajar yang dimiliki guru sebagai bahan pertimbangan penentuan sampel. Kemudian dipilih kelas yang memiliki nilai rata-rata tertinggi sebagai sampel yang representatif. Sampel dari penelitian ini adalah salah satu kelas VII yaitu kelas VII C.

\section{Intrumen dan Teknik Pengumpulan Data}

Angket merupakan instrumen yang berisi seperangkat pertanyaan atau pernyataan tertulis kepada responden untuk dijawab. Format angket yang digunakan adalah bentuk pernyataan yang harus dijawab dengan "ya" dan "tidak" disertai dengan alasan jawaban responden, dalam hal ini yaitu siswa.

Penelitian ini menggunakan dua angket yang digunakan yaitu angket respon siswa terhadap pelajaran IPA dan angket respon siswa terhadap model levels of inquiry. Pengolahan data angket dilakukan dengan mengklasifikasikan tanggapan siswa menggunakan skala Guttman. Jawaban tersebut dibuat dalam bentuk persentase. 
HASIL PENELITIAN DAN tidak berani untuk bertanya pada saat

\section{PEMBAHASAN}

Profil umum siswa merupakan gambaran informasi mengenai subjek penelitian, yaitu kelas VII C yang diperoleh dari angket sebagai respon siswa mengenai pelajaran IPA secara umum. Berdasarkan angket respon siswa, hanya $20 \%$ dari 30 responden siswa yang menjadikan matapelajaran IPA sebagai mata pelajaran yang paling disukai. Namun, sebanyak 53,3\% masih menyukai IPA walaupun yang disukai adalah mata pelajaran yang lain. Hal ini menunjukkan siswa masih memiliki motivasi dalam pelajaran IPA walaupun jumlahnya $53,3 \%$

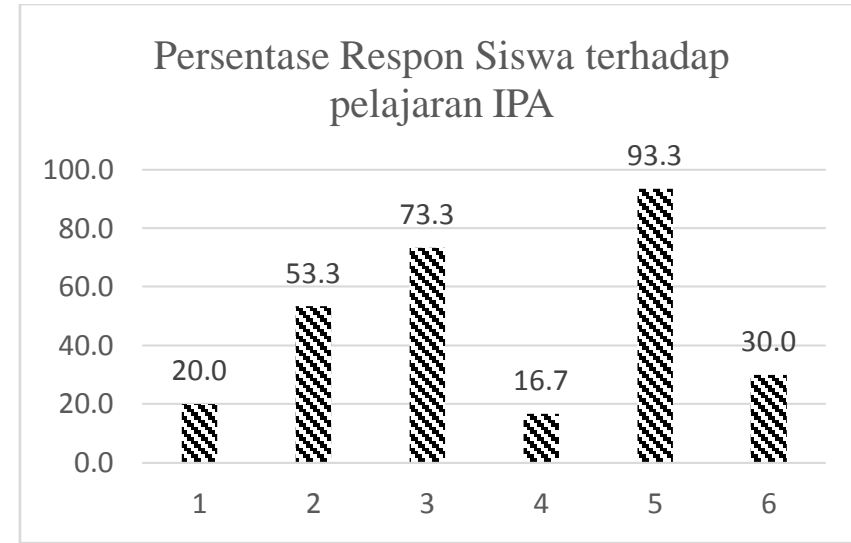

\section{Gambar 1. Presentase respon siswa terhadap pelajaran IPA}

Kedua hal di atas dimungkinan karena siswa merasa kesulitan dalam mempelajari konsep-konsep dalam pelajaran IPA. Ini tergambar pada jawaban angket nomor 3 yang menunjukkan $73,3 \%$ responden mengalami kesulitan tersebut. Mengenai hubungannya dengan ketakutan untuk bertanya, tampak bahwa hanya sebagian kecil responden yang mengalami kesulitan, yaitu sejumlah 16, $7 \%$. Hal ini menunjukkan bahwa walaupun sebagian besar siswa mengalami kesulitan dalam mempelajari konsep dalam pelajaran IPA, namun hanya sebagian kecil yang memiliki ketakukan untuk bertanya kepada guru.

Dari segi pembelajaran, hampir semua responden menyukai metode belajar praktikum, yaitu sejumlah 93,3\% responden. Dari informasi ini maka tepat apabila selama pengambilan data, model pembelajaran yang digunakan adalah levels of inquiry yang dalam pembelajarannya menggunakan praktikum untuk setiap sub pokok bahasan. Dari segi minat siswa untuk mengikuti kegiatan belajar IPA diluar sekolah hanya sebagian kecil yang melakukannya, yaitu 30\% responden. Hal ini menunjukkan bahwa siswa lebih fokus pada pembelajaran IPA di dalam sekolah di banding di luar sekolah. Namun informasi ini juga menunjukkan kebutuhan responden mengenai pelajaran IPA di sekolah belum sepenuhnya terpenuhi dan memilih mengikuti kegiatan belajar IPA di luar sekolah agar lebih memahami materi pelajaran. 


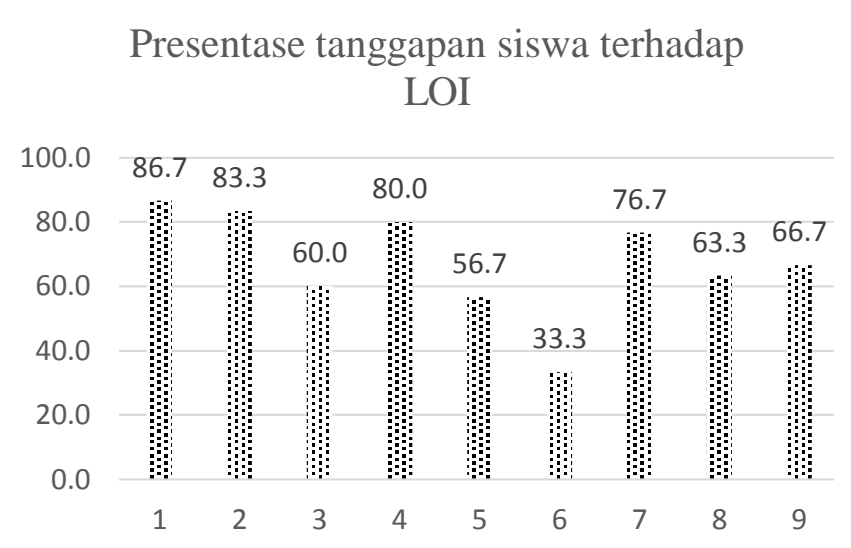

Gambar 2. Presentase respon siswa terhadap LOI

Berdasarkan angket respon siswa, dapat dikatakan bahwa hampir semua siswa $(86,7 \%)$ menyukai pembelajaran yang dilakukan dengan model levels of inquiry dengan berbagai alasan, seperti dapat lebih aktif belajar, menyenangkan, lebih memahami materi yang disajikan, menemukan konsep sendiri dan menjadi lebih bersemangat. Hal ini menunjukkan bahwa siswa siap belajar karena telah biasa melakukan pembelajaran levels of inquiry dan memiliki motivasi yang tinggi untuk melakukannya selama pengambilan data.

Mengenai respon siswa, guru yang bersangkutan mengatakan bahwa pembelajaran yang dilakukan lebih menyenangkan untuk siswa karena siswa bisa ikut serta secara aktif dan langsung tanpa pasif lagi seperti kegiatan pembelajaran sebelumnya.Peran praktikum dalam pembelajaran levels of inquiry yang telah di lakuka mampu membuat siswa senang dan memotivasi kegiatan pembelajaran karena siswa lebih menyukai banyak kegiatan yang dilakukan dibandingkan

dengan mendengarkan ceramah atau teori yang panjang. Berdasarkan hasil pengamatan dan pengalaman melakukan kegiatan pembelajaran ini, ia menyatakan bahwa pembelajaran ini dapat dilakukan dengan baik karena apabila terdapat keterbatasan alat, guru dapat menggantinya dengan animasi atau video pembelajaran yang berhubungan dengan materi yang akan disampaikan.

Kendala yang terdapat pada penerapan pembelajaran ini adalah kesulitan untuk memperkenalkan pembelajaran yang bertahap dengan tahapan yang cukup panjang dan terkadang membuat beberapa siswa kebingungan pada awal penerapannya, namun dapat diatasi seiring berjalannya penerapan pembelajaran ini pada tahap selanjutnya.

\section{SIMPULAN DAN SARAN}

\section{Simpulan}

Berdasarkan hasil analisis data dan pembahasan maka dapat disimpulkan bahwa respon siswa dan guru sangat positif terhadap pembelajaran levels of inquiry yang dilakukan. secara kuantitatif dapat dikatakan bahwa hampir semua siswa $(86,7 \%)$ menyukai pembelajaran yang dilakukan dengan model levels of inquiry dengan berbagai alasan, seperti dapat lebih aktif belajar, menyenangkan, lebih memahami materi yang disajikan, menemukan konsep sendiri dan menjadi lebih bersemangat.

\section{Saran}


Penulis memberikan rekomendasi aplikatif mengenai model levels of inquiry yang dapat dijadikan salah satu alternative pembelajaran untuk yang efektif dan mampu meningkatkan hemampuan berpikir tingkat tinggi siswa sehingga siswa mampu mengkonstruksi pengetahuannya secara mandiri.

\section{DAFTAR PUSTAKA}

Best, John. \& Kahn. (2006). Research in Education, Tenth Edition. Pearson Education Inc.

Cresswell. (2009). Research Design, Qualitative, Quantitative and Mixed Methods Approaches, Third Edition. SAGE publications. Thousand Oaks California 91320

Hofstein, A., Navon, O., Kipnis, M., \& Mamlok-Naaman, R. (2005). Developing students' ability to ask more and better questions resulting from inquiry-type chemistry laboratories. Journal of research in science teaching, 42(7), 791-806.

Mustikaweni, R, dkk. (2015). Pengaruh Respon Siswa Terhadap Model Pembelajaran Inkuiri Terbimbing dalam Menghadapi Masyarakat Ekonomi Asia. Seminar Nasional Fisika dan Pembelajarannya 2015 Surabaya :TheLearning University.

National Research Council. (1996). National Science Education Standards. Washington: National Academy Press.

National Research Council. (2000). Inquiry and National Science Education Standards. A Guide for Teaching and Learning. Washington DC: National Academy Press.

Novia. (2015). Pengembangan penalaran ilmiah pada pembelajaran IPA terpadu dengan menggunakan model levels of inquiry (Suatu Kajian Teoritis). Jurnal Pendidikan IPA Indonesia (JPII volume
4 nomor 1, halaman 19-25, April 2015)

Universitas Negeri Semarang

Novia, Riandi. (2017). The Analysis of Students Scientific Reasoning Ability in Solving the Modified Lawson Classroom Scientific Reasoning (MLTCSR) Problems by Applying the levels of Inquiry. Jurnal Pendidikan IPA Indonesia (JPII volume 6 nomor 1, halaman 116-122, April 2017) Universitas Negeri Semarang

Novia, Riandi. (2018). A Study on Levels of Inquiry: A Quantitative Descriptive for Analyzing Science Learning on Linear Motion Topic. First Indonesian Communication Forum of Teacher Training and Education Faculty Leaders International Conference on Education 2017 (ICE 2017). https://www.atlantis-press.com/

Rustaman. (2005). Perkembangan penelitian pembelajaran berbasis Inquiry dalam pendidikan sains. Seminar Nasional II Himpunan Ikatan Sarjana dan Pemerhati Pendidikan IPA Indonesia bekerjasama dengan FMIPA UPI Bandung.

Rustaman, dkk. (2007). Assesmen dalam Pembelajaran Sains. Bandung : Prisma Press.

Sukmadinata, N. S. (2012). Metode Penelitian Pendidikan" penelitian memberikan deskripsi, eksplanasi, prediksi, inovasi, dan juga dasar-dasar teoritis bagi pengembangan pendidikan. Bandung: PT Remaja Rosdakarya.

Suprihatin, E dan Hidayah, Y. (2014). Penerapan Model Pembelajaran Inkuiri Terbimbing pada Konsep Pencemaran Lingkungan dalam Melatih Keterampilan Menyelesaikan Masalah Siswa Kelas VII MTs AtThohiriyahLentera Jurnal Ilmiah. 9 (2): 11-24. Diaksestanggal 12Juni 2015.

Wenning, C.J. (2005). Levels of inquiry: Hierarchies of pedagogical practices and inquiry processes. Journal of Physics Teacher Education Online, 2(3), February 2005, pp. 3-12. 
Wenning, C.J. (2005). Implementing inquirbased instruction in the science classroom: A new model for solving the impeovement-of-practice problem. Journal of Physics Teacher Education Online, 2(4), pp. 9-15

Wenning, C.J. (2005). Implementing inquirbased instruction in the science classroom: A new model for solving the impeovement-of-practice problem. Journal of Physics Teacher Education Online, 2(4), pp. 9-15

Wenning, C.J. (2010). Levels of inquiry: Using Spectrum learning sequences to teach science. Journal of Physics Teacher Education Online, 2(3), pp. 11-20.

Wenning, C.J. (2011). The Levels of inquiry Model of Science teaching. Journal of Physics Teacher Education Online, 6(2), pp. 9-16. 